\title{
DIETARY ASSESSMENT OF MARWARI COMMUNITY OF JORHAT, INDIA
}

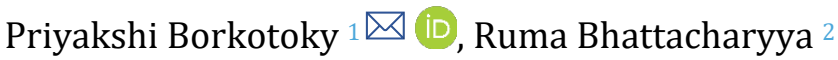 \\ ${ }^{1}$ Piramal Swasthya Management and Research Institute, Guwahati, Assam, India \\ 2 Department of Food Science and Nutrition, College of Community Science, Assam Agricultural University, \\ Jorhat-785 013, Assam, India
}

\section{Received 8 November 2021 \\ Accepted 18 December 2021 \\ Published 31 January 2022 \\ Corresponding Author \\ Priyakshi Borkotoky, \\ priyakshiborkotoky@yahoo.com \\ DOI \\ 10.29121/granthaalayah.v10.i1.2022 .4457}

Funding: This research received no specific grant from any funding agency in the public, commercial, or not-for-profit sectors.

Copyright: (C) 2022 The Author(s). This is an open access article distributed under the terms of the Creative Commons Attribution License, which permits unrestricted use, distribution, and reproduction in any medium, provided the original author and source are credited.

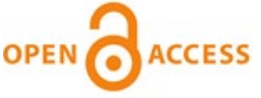

\section{ABSTRACT}

Nutritionally animal proteins are better for its superior bioavailibity, however due to the presence of high saturated fat content in food of animal origin, vegetarian diets are widely considered as healthy. But due to lack of proper information the nutritional adequacy of vegetarian diet followed by different communities is still uncertain. The Marwari is a strict ethnic vegetarian community of Indian, originated from Rajasthan, India. Due to business purpose a fraction of the Marwari community migrated to and residing at Jorhat, India. In view of lack of information on nutritional status of this particular community, a study was conducted to determine their nutrient intakes and variability in diets and dietary risk factors, weighing against similar values among Marwaries residing in Rajasthan. Total 200 samples were randomly selected and information on demographic profile, anthropometry, dietary habit, and health status of the sample population were collected with the help of an interview schedule and a pretested food frequency questionnaire. Findings were presented as percentage or mean with standard error. The food culture of the Assamese Marwari community is established within the traditional Marwari diet frame with strict vegetarianism and high fat diet, mostly contributed by clarified butter or desi ghee. However, the diet of the sample population was influenced by dissimilarity in agro climatic condition between Rajasthan and Assam. This study evaluates the dietary pattern, influence of environmental factor on traditional diet pattern due to migration and prevalence of risk factors of coronary heart and/or other non-communicable diseases among the sample population.

\section{Keywords: Marwari, Vegetarian, Dietary Pattern, Food Intake}

\section{INTRODUCTION}

Dietary culture, analysis of food components, foods and dietary patterns of a population confirms the association between dietary practice of the community and health. Earlier, the link of a particular food component with any disease would give more importance and experiments are carried out on multiple diverse populations to establish the nutrient and disease relation for policy interventions. In this regard, instead of studying the effect of particular dietary pattern on health, more emphasis has been given on the food component or nutrient. This is a limited approach of gathering knowledge on comprehensive benefits of a particular food's component in different situations only as the action of that particular food component on health may differ bases on its interactions with other food components present in the whole food or dietary practice David et al. (2011). In last few years, dietary analysis had been materialized as a substitute and complementary approach to find out the risk of health particularly NCD associating with diet in a community Rosemary et al. (2016). Dietary pattern 
evaluation and analysis signify a broader picture of food and nutrient consumption and their impacts on dietary parameters of a population Moreiras et al. (2010). But correct measurement of food and nutrient intake is decisive in a nutrition assessment study. This is because it can be used as markers to analyse the quality of diet intake Kerver et al. (2006) and probable associated risk of diet induced health problems. For example, diet is a modifiable risk factor of NCD and occurrence probability of NCD may be determined by exploring the dietary habit of an individual or community.

Dietary habit or meal pattern of a family or community normally develops over several generations and dictated by the geographic region, religion, etc. Mudambi and Rajagopal (2009). This is the main reason for existence of common ailments in a particular society or community. Environmental changes, food production pattern alteration and time might be factors for gradually modification in a traditional meal pattern. For instance, India has experienced a notable transformation in nutrition scenario in last few decades along with alteration in agricultural field. Correspondingly this has changed the disease pattern in the country. Similarly study of dietary pattern of immigrant population confirms dietary modification due to environmental changes and these modifications were associated with their healthrelated issues $\mathrm{Hu}$ (2002). These environmental changes control the sources of food production, availability, and distribution and affects food procurement, the type of meals prepared at home. So, it is essential to study the nutritional status, dietary habits, food availability of any migrated populations who have different social and environmental exposures from the parent population Singh et al. (2007).

The Marwari is a major vegetarian community of India originated from Marwar in Rajasthan. The word Marwar is derived from the Sanskrit word 'Maruwat' which means 'the region of desert. People in Rajasthan use minimum water and prefer milk, butter milk, and clarified butter due to the geographical condition. The main profession of Marwari people is business and for this reason they accustomed to migrated to different places to expand their trade. But generally, it is observed that in spite of their new address Marwari people stick to their traditional Rajasthani food habit. Rajasthani foods are mostly popular for use of high amount of clarified butter or desi ghee in all recipes. This might be an associated aspect of prevalence of various coronary risk factors such as Diabetes (history), Hypertension, Obesity (BMI) and Truncal obesity at the rate $04 \%, 13.2 \% 10.9 \%$ and $20.8 \%$, respectively among rural population of Central Rajasthan Gupta et al. (1994). A sizeable section of Marwari people is settled in Jorhat Town of Assam, India. Till date no afford has been made to explore their health and nutritional status though it is essential as per public health nutrition standpoint.

So, in view of scanty information on health and nutritional status of Marwari people settled in Jorhat, Assam, this study was carried out to elicit information on their food habit, its relation to health and presence of any risk factors of NCD and CHD primarily. The study also appraises the impact of environmental factor on traditional diet pattern due to migration among the sample population.

\section{METHODS}

\subsection{SAMPLE SELECTION}

Total 200 samples irrespective of sex and age between 25 to 65years were selected from 4 municipal wards of Jorhat town belonging to Marwari community by the purposive random sampling method. An interview schedule was formulated to elicit information on socioeconomic background (name, sex, age, income, 
profession, working hours, educational level, marital status, etc.) and the medical history of the sample population was drawn out by direct interview method.

\subsection{DATA COLLECTION AND ANALYSIS}

A food frequency questionnaire (FFQ) was developed based on information received through focused group analysis on food items reported to be used by the sample population and pre-tested. This FFQ was used to get detail information on diet consumed Sarma (2001), Rosemary et al. (2016),Coulston et al. (2012). In order to avoid any possible under and/or overestimation by the FFQ, estimates were compared with the 24 hours weighed records using a portable weighing balance, measuring spoons and cup. This was done to presume the approximately accurate portion size information on each food item and minimize dietary information error. The portion size information was used to calculate the nutrient intakes using the standard nutritive value of Indian food items Hearty and Gibney (2008), Gopalan et al. (2009),Pasricha (2000) for energy, protein and fat. Results of nutrient intakes were compared with the Recommended Dietary Allowances (RDA) ICMR (2011) for Indians. Percentages of respondents and mean values with standard error of means against each indicator were calculated for presentation of findings. Existence of any risk factors of metabolic diseases is presented in percentage.

\subsection{ANTHROPOMETRY}

The Body Mass Index (BMI) is an internationally accepted standard and objective measure of body weight in relation to height. It is highly correlates with obesity and hence used to assess the nutritional status of the studied population. BMI was computed using the following formula

$$
\mathrm{BMI}=\frac{\text { Body weight in }(\mathrm{kg})}{\text { Height }^{2}\left(\mathrm{~m}^{2}\right)}
$$

Similarly, the Waist Hip Ratio (WHR) of an individual is a marker of central obesity. This has calculated as

$$
\text { WHR }=\frac{\text { Waist circumference }(\mathrm{cm})}{\text { Hip circumference }(\mathrm{cm})}
$$

The calculated values of BMI and WHR were examined according to the Garrows BMI classification (1987) and Croft et al. classification (1995).

\section{RESULTS}

\subsection{SOCIO- DEMOGRAPHIC}

Majority of the sample population (42.5\%) belonged to the joint family system and 93 per cent population was from high income family category. The main mode of income of the sample population was business. Total $95.5 \%$ female were housewives, 4.5 per cent females were engaged in business. The percentages of married males and females were 89.5 and 100, respectively. About 11.5 percent females were identified as illiterate and male literacy rate was $100 \%$. 


\subsection{DIETARY}

As per the information obtained on dietary habit through a food frequency questionnaire, cent per cent population was vegetarian and the diet was divided into three main meals - breakfast, lunch, and dinner. In between main meals, the studied population had the habit of having tea or fruit juice. Results of the food frequency questionnaire indicate that the desi ghee or clarified butter was the chief cooking media in all dishes. The daily menu consists of different traditional Marwari dishes. The Table 1 depicts the percentage distribution of sample population according to frequency of consumption of different food items.

Table 1 Percentage distribution of respondent according to frequency of consumption of different food items

\begin{tabular}{|c|c|c|c|c|c|c|}
\hline Item & $\begin{array}{c}\text { Daily } \\
\text { (\%) }\end{array}$ & Once & per week & Twice per week & Occasionally & Never \\
\hline \multicolumn{7}{|c|}{ Break fast } \\
\hline Paratha & 89 & - & & 2 & 0 & 9 \\
\hline Tikra & 2.5 & 1.5 & & - & 10 & 86 \\
\hline Phulka & 9 & 0 & & - & 2 & 89 \\
\hline Gehupuri & - & 15.5 & & - & 13 & 71.5 \\
\hline Sabipuri & - & 4 & & 7.5 & 24 & 64.5 \\
\hline Missi roti & - & 2 & & 4 & 26.5 & 67.5 \\
\hline Seasonal Sabji & 88 & - & & - & 6 & 6 \\
\hline Pickle & 76 & - & & 2.5 & 10 & 11.5 \\
\hline Curd & 39.5 & 2 & & - & 5.5 & 53 \\
\hline Mixture & 20 & - & & - & 5.5 & 74.5 \\
\hline Bread/ toast & 4.5 & - & & - & 2 & 93.5 \\
\hline Milk & 18.5 & - & & - & 0 & 81.5 \\
\hline Fruit drink & 7 & - & & - & 5.5 & 87.5 \\
\hline Health drink & 0 & - & & - & 0 & 100 \\
\hline Tea & 61.5 & - & & - & 1 & 37.5 \\
\hline \multicolumn{7}{|c|}{ Lunch } \\
\hline Chawal & 82.5 & & - & - & 0 & 17.5 \\
\hline Dhal & 97 & & - & - & 2 & 1 \\
\hline Paratha & 13 & & - & 1 & 14.5 & 71.5 \\
\hline Sangri & 4.5 & & 4.5 & 2 & 51.5 & 37.5 \\
\hline Gatta & 17.5 & & 3 & 2.5 & 58.5 & 18.5 \\
\hline Dalia & - & & - & - & 49 & 51 \\
\hline Phulka & 86.5 & & - & - & 12 & 1.5 \\
\hline Cuddy & 36 & & - & 2.5 & 15 & 46.5 \\
\hline Began ka & 5 & & 0.5 & 0.5 & 16 & 78 \\
\hline Salad & 86 & & - & - & 14 & - \\
\hline Seasonal Sabji & 76 & & 8 & 13.5 & 2.5 & - \\
\hline Papad & 99 & & - & - & - & 1 \\
\hline Curd & 53 & & 4.5 & - & 8.5 & 34 \\
\hline Khichdi & - & & - & - & 5.5 & 94.5 \\
\hline Chutney & 89 & & - & - & 11 & 0 \\
\hline Pickle & 94 & & - & - & 4 & 2 \\
\hline \multicolumn{7}{|c|}{ Evening } \\
\hline Tea & 83.5 & & - & - & - & 16.5 \\
\hline Snacks & 78 & & - & - & - & 22 \\
\hline
\end{tabular}




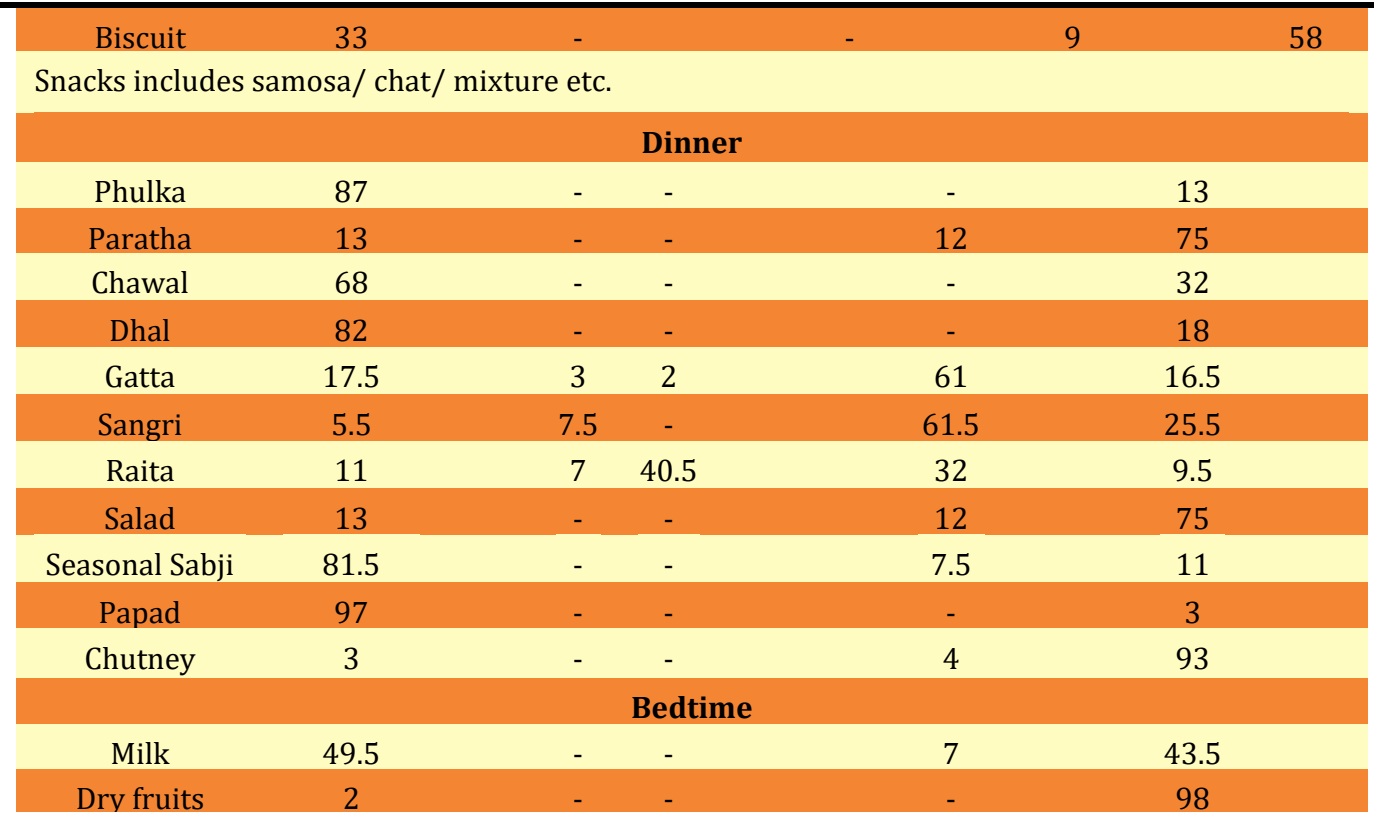

\section{Breakfast}

During breakfast $89 \%$ of the subjects consumed paratha, 9\% phulka, 2.5\% tikra prepared with desi ghee. Other breakfast items were seasonal sabji (88\%), curd $(39.5 \%)$, pickle $(76 \%)$, etc. In breakfast they preferred to have milk tea $(61.5 \%)$ instead of milk and $20 \%$ of the population liked to eat mixtures, such as bhujia with tea. $7 \%$ of the population used to have drinks like fruit juice in breakfast.

\section{Lunch}

During lunch time the population consumed rice (82.5\%) and phulka (86.5\%) or paratha (13\%) with dhal (97\%), seasonal sabji (76\%), gatta (17.5\%) sangria (4.5\%), and cuddy (36\%). Pickle (84\%), salad (86\%), chutneys (89\%), and papad (99\%) were common in lunch. 53\% population liked to have to curd.

\section{Evening}

In evening $83 \%$ population took tea with biscuit (33\%) or other snacks (78\%) like bhujia, chana, chat, nimki, samosa, etc.

\section{Dinner}

Dinner was almost similar to lunch except the amount of item consumed. Normal menu was paratha $(87 \%)$ or pulka $(13 \%)$ and rice $(68 \%)$ with dhal $(82 \%)$, seasonal sabji (81.5\%), sangria (5.5\%), gatta (17.5), salad (13\%), chutney (3\%) and papad (97\%). No one took curd at night. At bedtime $49.5 \%$ population consumed milk and $2 \%$ took dry fruits.

The average cereal intake for female and male were $350 \mathrm{~g} /$ day and $380 \mathrm{~g} /$ day respectively. The average pulse intake $(120 \mathrm{~g} /$ day) was pretty high. The average intake of fruits and vegetables was 270 g per day. Pumpkin, bottle gourd, bitter gourd, tomato, potato, capsicum, beans, and carrot were regularly consumed common fresh vegetables by the sample population. The population preferred to have citrus fruits like lemon, orange, and high-water containing fruits like melon most. The daily intake of fresh cow's milk by the respondents was $280-350 \mathrm{ml}$. Milk was used as drink and also in different preparations like kheer, halwa, raita, cuddy, etc. At bedtime, 49.5 per cent sample population consumed milk. Cent percent respondents consumed clarified butter and it was the main cooking media for regular use. Other main fats and oils consumed by the population were mustard oil, butter, and refined oil. The average visible fat intake was $49.8 \mathrm{~g} /$ day. The daily 
dietary intake food group wise and the mean nutrients intake of the sample population according to the sex and age group are shown in Table $2 \&$ Table 3.

\begin{tabular}{|ccc|}
\hline \multicolumn{2}{|c|}{ Table 2 Dietary intake of the sample population according to food groups } \\
\hline Food Group & Food Intake (g/person/day) & RDA (g/person/day) \\
Cereal & $350-380$ & 400 \\
Pulse & 120 & 80 \\
\hline Fruits and vegetables & 270 & 400 \\
\hline Milk and milk products & $280-350^{*}$ & $300^{*}$ \\
Fats and oils & 49.8 & 30 \\
\hline ml/person/day(Source: ICMR, 2011) & & \\
\hline
\end{tabular}

Table 3 Mean intake of the Energy, Protein and Fat of sample population according to the age group

\begin{tabular}{cccccccc}
\hline Nutrients & Sex & $\mathbf{2 5 - 3 4 y r}$ & $\mathbf{3 5 - 4 4 y r}$ & $\mathbf{4 5 - 5 4 y r}$ & $\mathbf{5 5 - 6 5 y r}$ & Average intake & RDA \\
\hline Energy & Male & 2230.08 & 2216.63 & 2211.09 & 2188.9 & $2211.68 \pm 17.15$ & 2730 \\
& Female & 2166.25 & 2141.9 & 2145.71 & 2103.87 & $2139.43 \pm 26$ & 2230 \\
Protein (g) & Male & 75.71 & 75.9 & 74.82 & 73.49 & $75 \pm 1.1$ & 60 \\
& Female & 71.58 & 74.39 & 73.56 & 70.46 & $72.5 \pm 1.8$ & 55 \\
Fat (g) & Male & 71.62 & 72.79 & 70.34 & 71.65 & $71.6 \pm 1.0$ & 30 \\
& Female & 71.45 & 69.65 & 69.84 & 67.93 & $69.7 \pm 1.44$ & 25
\end{tabular}

\subsection{ANTHROPOMETRY}

\section{BMI}

In case of male respondents, a gradual increase in BMI is observed with age. The average BMI of men within 25 to 34 years was 24.7 , which is within the normal BMI range. But males with age under 35 to 65 years, were overweight and had BMI from 25.38 to 261.18 (Table 4). Though similar trend was observed, but BMI of females was slightly different. BMI of 25-34 years age group and 35-44 years age group women were 23.96 and 24.84 respectively. Females of age group 45 to 54 and 55 to 65 were having BMI of 26.38 and 28.9. That signifies that women age between 45 to 65 years were overweight.

\begin{tabular}{|cccc|}
\hline \multicolumn{4}{|c}{ Table 4 Mean BMI \& WHR of respondents } \\
\hline Gender with Age group & No of sample & BMI & WHR \\
\hline Male (25-34) & 34 & $24.70 \pm 0.18$ & $0.918 \pm 0.006$ \\
\hline Male (35-44) & 27 & $25.38 \pm 0.27$ & $0.926 \pm 0.530$ \\
\hline Male (45-54) & 5 & $25.99 \pm 0.53$ & $0949 \pm 0.001$ \\
\hline Male (55-65) & 21 & $26.18 \pm 0.40$ & $.0808 \pm 0.005$ \\
\hline Female (25-34) & 64 & $23.96 \pm 0.36$ & $0.808 \pm 0.005$ \\
\hline Female (35-44) & 21 & $24.84 \pm 1.7$ & $0.826 \pm 0.007$ \\
\hline Female (45-54) & 15 & $26.38 \pm 0.47$ & $0.858 \pm 0.007$ \\
\hline Female (55-65) & 13 & $28.9 \pm 0.58$ & $0.863 \pm 0.009$ \\
\hline
\end{tabular}

\section{WHR}

As per Croft et al. if the ration of waist to hip girth is more than 0.95 in males and 0.8 in female, the person is having central obesity which is a known risk factor of coronary heart diseases (CHD). This assessment was done among the sample population and was found that all male respondents were having the WHR below 0.95 and all females were identified with high WHR (Table 4). 


\section{DISCUSSION}

In history, Marwaris are the most triumphant and richest business community in India. Marwaries are diaspora in nature since long-ago and expansion of business was one of the major causes of migration of Mawaries from Marwar. As per the Census (1961) around 7\% Mawaries were settled outside Rajasthan in India Mukherjee (2011). Marwari is a male dominated community where females are mostly engaged with household activities. Teen age marriage, poor literacy rate among girls is a major social issue in Rajasthan. The study was evaluated based on the demographic profile, average nutrient intake, diet modification, influence of agro climatic condition on food habit of the studied population.

\subsection{DEMOGRAPHIC PROFILE}

The common and solo mode of income of $100 \%$ male and $4.5 \%$ female respondents of the community was business. Like men, Marwari women are also good in business and as per a study $28.9 \%$ women were engaged in some income generation activity in urban Rajasthan Agarwal and Verma (2015). During the data collection period, no female was unmarried between 25-65 years of age, and no one was divorced or separated from the family. The population preferred to live in joint family type with dual property holding in Assam and Rajasthan individually or as whole with the family. As per the NFHS-4 MoHFW (2016) report the literacy rate of men and women in Rajasthan were higher in urban area $(92.4 \% \& 75.8 \%)$ as compared to rural area (82.6\% \& 49.8\%). But among the studied population, $0 \%$ males and only $11.5 \%$ women were found illiterate during the study.

\subsection{DIETARY HABIT}

The principal harvested food grains of Rajasthan are cereals such as rice, wheat and millets like jowar, bajra, maize, ragi. Others include pulses, ground nut, sesame. Millets, lentils, and beans are the most basic ingredients in their food. Gram flour is a major ingredient in the preparation of traditional food items like ghatta ki sabzi, pakodi and khata. The staple food items of Rajasthan are rotis, rabdi, and khichdi maid from bajra and corn. Many vegetables and certain berries (like kair and debra) are sun-dried and preserved for the year. Similarly, other parts of the plant like fruits (bijoda), stems and roots (garmar), and even certain aromatic twigs (sanghar) are also hydrated for preservation. Rajasthan is affluent in dairy products and items like desi ghee, curd, malai, makhan, plain milk, lassi, paneer etc are abundantly used by the population for dietary purpose.

The food group wise consumption pattern of the population placed at Table 2 portrays that the sample population falls under the lacto- vegetarian community as they took only milk, and no other animal food products. The milk consumption quantity among the sample population was quite high and it was a major source of protein $(8.96-11.2 \mathrm{~g})$ as well as fat $(11.48-14.35 \mathrm{~g})$ in the diet. Milk was consumed as drink, curd, paneer, and sweet items. Milk contributed $12.2-15.1 \%$ protein in daily diet of the respondents, and it was close to $15.47 \%$ protein from milk as mentioned in Nutrient Intake of India NSSO (2007) for urban Rajasthan. The total intake of milk by the respondents was ranged from 280 to $350 \mathrm{ml} /$ person/day analogous to $329.8 \pm 40.57 \mathrm{ml}$ milk intake per day per person by women of urban Rajasthan Agarwal and Verma (2015). The average milk and milk product 
consumption by the sample population was slightly higher than the RDA for milk (300ml) as per ICMR ICMR (2011).

Cereal like wheat and rice were the main source of energy in the diet of respondents. Common cereal items include phulka, paratha, tikra, rice etc. The average consumption of cereal by the population was 350-380 (g/person/day) which was less than RDA (600/day) for Indian ICMR (2011). Cereals are the major source of energy in daily diet of the sample population which had similitude with 49.21\% NSSO (2014) and 59.73\% MoSPI and WFP (2019) of energy shared by cereal in diet of people of urban Rajasthan. But low cereal consumption was interconnected to overall negative calorie balance diet of the population.

The fat consumption pattern of the sample population $(69.79 \mathrm{~g} /$ day) was as high as in urban Rajasthan (66.7g/day) MoSPI and WFP (2019). The average fat intake of urban women age in between 35 to 70 years of Jaipur city of Rajasthan was reported to be $67.41-74.4 \mathrm{~g} /$ day Agarwal and Verma (2015). The major portion of fat was contributed by desi ghee and other sources were mustard oil, refined oil, butter, and milk, etc. The average fat consumption of the studied population was $70.6 \mathrm{~g}$ per day out of which $49.8 \mathrm{~g}$ comes from visible sources and $20.8 \mathrm{~g}$ comes from invisible fat sources. Fat consumption value was much higher that the RDA (25 to 30/day) for fat in diet ICMR (2011).

Next to milk, pulses were the important source of protein in diet of respondents. All types of pulses, legumes were consumed in high amount by the sample population. Green gram and Bengal dhal were the most preferred pulses. Powdered pulses were used for recipes like cuddy, pakora, bada, gatta etc. Other snack items such as roasted/ fried Bengal gram, green gram, sprouts etc contribute to pulses consumption in the diet. The average pulses consumption was $120 \mathrm{~g} /$ day by the sample population. This value was higher than the recommended 75 to $90 \mathrm{~g} /$ day for pulses ICMR (2011). A study on women of Jaipur urban areas confirmed 28.47 $17.19 \mathrm{~g} /$ day pulse consumption Agarwal and Verma (2015). The NNBM reports, ICMR (2009) shows 50g pulses intake per day per person in Rajasthan and recognized as a high protein intake state. Same report documents a negative trend in pulse consumption in Rajasthan.

In Assam, Marwari people eat fresh fruits \& vegetables instead of persevered vegetables. The average daily intake was $270 \mathrm{~g} /$ day, which was lower than the RDA for vegetable and fruits (500+100 g/day) advised by ICMR ICMR (2011). Pumpkin, bottle gourd, bitter gourd, tomato, potato, beans, carrots were common vegetables in diet of the respondents. They prefer citrus fruits like lemon, sweet lime, orange, and high-water containing fruits such as watermelon. Whereas the average intake by women in Jaipur was reported to be $15.73 \pm 9.24,67.75 \pm 40.57 \& 55.11 \pm 25.57$ $\mathrm{g} /$ day for green leafy, roots $\&$ tubers and other vegetables respectively Agarwal and Verma (2015). Similarly low consumption (2/3 of RDA) of vegetables and negligible consumption of green leafy was reported among Gujrati vegetarians of India ICMR (2009).

Using the standard nutritive values of Indian food items, the nutritive value of consumed items was calculated for energy, protein, and fat Pasricha (2000). The age and sex wise mean intake of nutrient is presented in Table 3. The mean intake of energy by male and female population was $2211.7 \pm 17.15 \mathrm{kcal}$ and $2139.4 \pm 26 \mathrm{kcal}$, respectively. But these values were lower than RDA for man $(2730 \mathrm{kcal})$ and woman (2211.7 kcal). There was gradual reduction in energy consumption observed with age among male of 25 to 65 years. However apart from oldest group (55-65 years) among females, the energy consumption was quite similar. The average calorie intake of $3090 \mathrm{kcal}$ in rural and $2704 \mathrm{kcal}$ in urban Rajasthan during 1993-94 had been reduced to $2408 \mathrm{kcal}$ and $2320 \mathrm{kcal}$, respectively in 2011-12 NSSO (2014). The 
calorie contribution proportion of 57:14:29 shared by carbohydrate, protein, and fat in diet of the sample population was very much similar with urban Rajasthan's 63:11:26 ratio than the ration of 73:10:17 in Assamese diet of Assam, India NSSO (2014). Protein and fat intake in both the genders were much higher than the RDA for different age groups. The female population mainly belongs to the housewife category, which may have an influence on the habit of eating energy dense snacks in between main meals at home and this may be a reason of high calorie intake per day. From the NSSO reports NSSO (2007),NSSO (2014) it is evident that the overall protein and fat consumption is always higher than the RDA in Rajasthani diet. The average protein intake by people in Rajasthan was $69.6 \mathrm{~g}$ and $64 \mathrm{~g}$ per capita per day in rural and urban population in 2004-05 and $68.4 \mathrm{~g}$ and $62.7 \mathrm{~g}$ per capita per day in 2011-12. The average fat and protein intake Rajasthan was $66.7 \mathrm{~g} / \mathrm{person} /$ day for both fat and protein and similarly, these values were $39.2 \mathrm{~g} /$ person/ day and 55.49 $\mathrm{g} /$ person/ day for population residing in Assam NSSO (2014). So, it makes clear that the Marwari people living in Jorhat, Assam were trailing the similar fashioned dietary pattern with people in Rajasthan.

\subsection{ENVIRONMENTAL EFFECT}

Assam and Rajasthan share different agro climatic condition. Rajasthan has Trans-Gangetic Plains Region, Central Plateau and Hills Region, Gujarat Plains and Hills Region while Assam comes under the Eastern Himalayan Region. As per FAO FAO (2008), an agro-climatic zone means an area of land in terms of predominant climates that is befitting for a particular range or verity of agricultural produce and cultivars based on its physiography, soil quality, geological condition, climate, cropping pattern, facility of irrigation and mineral resources. So, it provides sufficient information to understand that the food availability was relatively diverse in both the states. Agriculture and fisheries depend on the agro climatic condition of a specific region and any change in climate affects food production and security through its impact on food chain FAO (2008). Regional differences with socioeconomic and agricultural factors were associated with household dietary diversity Sukhwinder et al. (2020). As per the NSSO report, NSSO (2007) in Rajasthan, maize, and other millets, such as bajra were equally popular cereal along with wheat and rice, but in Assam, Marwari people commonly use wheat and rice only. The sample population eat good number of fresh vegetables in Assam; in contrast Rajasthani diet was grossly deficient in green leafy vegetables and other vegetables Singh et al. (2007). Rajasthani people generally take two major meals per day, which was different from three meal pattern of Marwaries living in Jorhat town.

\subsection{PRIMARY RISK FACTORS OF METABOLIC DISORDERS}

The sample population followed the traditional Marwari food culture with little changes in frequency of eating, choice of items from different food groups and nutrient consumption. But predominantly $100 \%$ population use the clarified butter, a saturated fat for cooking. The high visible fat (49.6g/day) consumption by the population might be an invisible risk factor for any metabolic disorders in future Narasimhan et al. (2016). Moreover, low intakes of fruits \& vegetables with insufficient physical activity were considerably linked with the metabolic syndrome risk factors Verma et al. (2018) because specific nutrients have influence on fat metabolism Alicia et al. (2019). The consumption of fruits and vegetables $(270 \mathrm{~g} /$ day $)$ by the population might not providing enough vitamins, minerals, antioxidants, and dietary fibre to the diet of the respondents but it is better than Rajasthani diet. The prevalence of hypertension was 14.5\% (Table 5) among the 
sample population. As per the NFHS-4 MoHFW (2016),MoHFW (2016) report, the hypertension rate with a little higher than normal (Systolic 140-159 mm of Hg and/or Diastolic 90-99 $\mathrm{mm}$ of $\mathrm{Hg}$ ) was $6.4 \%$ and $11.6 \%$ among urban female and male adults (age 15-49 years) of Rajasthan, whereas it was $13.2 \%$ and $17.9 \%$ among female and males in Assam. So, trend of hypertension among the sample population is similar with Assamese people. During the study, total $17 \%$ sample population was diabetic (Table 5). 3.9\% urban women and 5.8\% men were reported to have high blood sugar level ( $>140 \mathrm{mg} / \mathrm{dl}$ ) in Rajasthan, in the same way these values were 7.2\% and 7.6\% in Assam MoHFW (2016),MoHFW (2016). This shows the prevalence of diabetes among the studied population was neither bear a resemblance neither to prevalence in Rajasthan nor to Assam. Among the studied population, $32.9 \%$ of total females specifically age between 45 -54years and $55-65$ years had grade I obesity with BMI of $26.38 \pm 0.47$ and $28.9 \pm 0.58$, respectively and all females had WHR above normal limit. In addition, total $31.8 \%$ male respondents were overweight with BMI 26.18 \pm 0.4 . According to the NFHS-4 report, the percentage of overweight or obesity (BMI $\geq 25$ ) among urban women and men in Rajasthan was 23.7 and 19.7. In contrast, in Assam it was 26.1 and 24.8. So, it was apparent that the trend of obesity among migrated Mawaries was close to Assamese people than Rajasthani natives. The high fat food intake of the community probably promotes weight gain among the sample population James et al. (2000). As the consumption of dietary fat ( $72.8 \mathrm{~g} /$ day) was fairly high ( $29 \%$ of total calorie) as compared to the RDA for Indians by the sample population in comparison to Rajasthani and Assamese community as a whole, it might be the reason behind their high pervasiveness of hypertension, diabetes and obesity.

\begin{tabular}{|ccc|}
\hline Table 5 Presence primary risk factor among the sample population \\
\hline Risk factor & No of respondents & Percentage \\
\hline Hypertension & 34 & 17 \\
\hline Diabetes & 29 & 14.5 \\
\hline
\end{tabular}

\section{CONCLUSION}

The present investigation reveals facts of nutritional significance of migrated Marwari people living in Jorhat town of Assam, India. The sample population is found to be followed the Rajasthani diet habit. Though there was alteration in fruits and vegetables consumption pattern, but the studied population was highly influenced by the traditional Marwari diet pattern in terms of frequency, quality, and quantity. The main finding that emerges was the dietary excess of fat intake and association with presence of metabolic risk factors of NCDs. The energy contribution by fat (mainly saturated fat) ranged between 29.14 to 29.32 percent mainly from animal source (milk and desi ghee) among different age groups was approximately equal to upper limit of fat for genesis of CHD. Though the risk factors of any metabolic disorder like hypertension, diabetes, obesity, sedentary habit, high fat intake were present among the sample population; high intake of pulse \& curd and avoidance of alcohol \& smoking habit may be considered as the preventive and protective measures against these risk factors. Pulses are rich in vitamins, minerals $\&$ antioxidant. Over and above dietary calcium of card has essential and important role in regulation of energy metabolism, which inhibits adipogenesis and improves insulin sensitivity. Daily supplementation of probiotics in curd is also a matter of advantage for NCD prevention. However, the towering prevalence of risk factors of metabolic disorders among the studied population as compared to people of Rajasthan, demands immediate awareness on issues like lifestyle and behavioural 
change. The studied population may be linked with the Ayushman Bharat Comprehensive Primary Healthcare (CPHC) program of Government of India for regular health screening and interventions like counselling, treatments, and referral MoHFW (2018). This study also makes available baseline information on diet and food habit of Marwaries migrated to Assam.

\section{ACKNOWLEDGMENTS}

One of the authors (PB) would like to express her sincere thanks to Dr. Gayatri Borthakur, Assam Agricultural University for providing support in all ways including idea sharing and guidance.

\section{REFERENCES}

Agarwal A \& Verma K (2015) Diet and Nutrient Intakes in Urban Women of Rajasthan State,Northern India, Ecology of Food and Nutrition doi: 10.1080/03670244.2015.1056875 - Source: PubMed Retrieved from https://doi.org/10.1080/03670244.2015.1056875

Alicia J. Maria del M B, Josep A (2019) Dietary fat intake and metabolic syndrome in adults : A systematic review, Nutrition, Metabolism and Cardiovascular Diseases 29, Suppl. 9 S887-S905 Retrieved from https://doi.org/10.1016/j.numecd.2019.05.055

Coulston AM, Boushey CJ \&Ferruzzi M (eds) (2012). Nutrition in the prevention and treatment of disease. ISBN -978-0-12-391884-0.

David R. Jacobs Jr., Linda C. Tapsell \& Norman J. Temple (2011) Food Synergy: The Key to Balancing the Nutrition Research Effort Public Health Reviews, 33:507-529. Retrieved from https://doi.org/10.1007/BF03391648

FAO (2008) Climate change and food security : a framework document. Rome : FAO

Gopalan C, Rama Sastri BV\& Balasubramanian SC (eds) (2009). Nutritive value of Indian foods. National Institute of Nutrition, Hyderabad, India.

Gupta R, Gupta HP, Keswani P et al. (1994) Coronary heart disease and coronary risk factor prevalence in rural Rajasthan. J Assoc Physicians India 42. Suppl.1, S 21-26 Retrieved from https://europepmc.org/article/med/7836242

Hearty AP \&Gibney MJ (2008). Analysis of meal patterns with the use of supervised data mining techniques - artificial neural networks and decision trees. Am J ClinNutr $88 \quad$ : $\quad 1632-1642 . \quad$ Retrieved from https://doi.org/10.3945/ajcn.2008.26619

Hu FB (2002). Dietary pattern analysis : à new direction in nutritional epidemiology. CurrOpinLipidol13(1) : 3-9. Retrieved from https://doi.org/10.1097/00041433-200202000-00002

ICMR (2009), NNMB Report, Hydrabad, NIN, I India.

ICMR (2011) Dieatry guidelines for Indians: A Manual. Hyderabad : NIN, India.

James O. Hill, Edward L. Melanson, Holly T. Wyatt (2000) Dietary Fat Intake and Regulation of Energy Balance : Implications for Obesity he Journal of Nutrition, 130, Issue 2, S 284- S288. Retrieved from https://doi.org/10.1093/jn/130.2.284S

Kerver JM, Yang EJ, Obayashi S, Bianchi L \& Song WO (2006). Meal and snack patterns are associated with dietary intake of energy and nutrients in US adults. JAm Diet Assoc 106(1) : 46-53. Retrieved from https://doi.org/10.1016/j.jada.2005.09.045 
MoHFW (2016) National Family Heath Survey of India : State Fact Sheet (Assam) . Joint MoHFW, USAID,UKaid, Bill \& Melinda Gates Foundation, UNICEF, UNFPA \& MacArthur Foundation Consultation. New Delhi : MoHFW, GoI.

MoHFW (2016) National Family Heath Survey of India : State Fact Sheet (Rajasthan) . Joint MoHFW, USAID,UKaid, Bill \& Melinda Gates Foundation, UNICEF, UNFPA \& MacArthur Foundation Consultation. New Delhi : MoHFW, GoI.

MoHFW (2018) AYUSHMAN BHARAT : Comprehensive Primary Health Care through Health and Wellness Centers : Operational guidelines, NHSRC,MoHFW, New Delhi,India

MoSPI \& WFP (2019) Food nd Nutrition Security Analysis, India. Joint MoSPI \& WFP Consultation. New Delhi : MoSPI, GoI

Moreiras V, Avila JM,Cuadrado C, Pozo S. Ruiz E \& Moreiras O (2010) Evaluation of food consumption and dietary patterns in Spain by the Food Consumption Survey: updated information European Journal of Clinical Nutrition ; 64:3743 Retrieved from https://doi.org/10.1038/ejcn.2010.208

Mudambi SR \& Rajagopal MV (2009). Fundamentals of Foods, Nutrition and Diet Therapy. New Age International, New Delhi, India.

Mukherjee K (2011) Marwari, In Rajasthan : Part-I, 29-142. India : Language Division Office of the Registrar General \& Census Commissioner Retrieved from

https://censusindia.gov.in/2011documents/lsi/lsi_rajasthan/5_marwari.p df

NSSO (2007) Nutritional Intake in India, 2004-2005. NSS Report No.513. New Delhi : MoSPI, GoI.

NSSO (2014) Nutritional Intake in India, 2011-12. NSS Report No. 560. New Delhi : MoSPI, GoI.

Narasimhan S, Nagarajan L, Vaidya R et al. (2016) Dietary fat intake and its association with risk of selected components of the metabolic syndrome among rural South Indians. Indian J Endocr Metab 20, S47-S54 Retrieved from https://doi.org/10.4103/2230-8210.172248

Pasricha S. (ed) (2000). Count what you eat. National Institute of Nutrition, Hyderabad, India.

Rosemary G, James M, Edward JM. J et al. (2016) Dietary patterns in India : à systematic review. $\mathrm{Br} \mathrm{J}$ Nutr. Published online ; doi : 10.1017/S0007114516001598. Retrieved from https://doi.org/10.1017/S0007114516001598

Sarma S (2001). Risk factors of coronary heart disease among vegetarians of Nagaon town of Assam, M.Sc. Thesis, College of Home Science, AAU, Jorhat, India.

Singh MB, Lakshminarayana J \& Fotedar R (2007). Studies on the Nutritional Status of Rural Population in Desert Area of Rajasthan. Tribal health : proceeding of National Symposium Vol 312 : 191-196. Retrieved from https://www.nirth.res.in/publications/nsth/25.MB.Singh.pdf

Sukhwinder S, Andrew D J \& Meha J. (2020) Regional differences in agricultural and socioeconomic factors associated with farmer household dietary diversity in India Published online : 16 April, doi.org/10.1371/journal.pone.0231107

Verma P, Srivastava RK, Jain D (2018) Association of lifestyle risk factors with metabolic syndrome components : A cross-sectional study in Eastern India. Int J Prev Med 9, Suppl. 1, S6 Retrieved from https://doi.org/10.4103/ijpvm.IJPVM_236_17 